\title{
Eosinophil Lineage-Committed Progenitors as a Therapeutic Target for Asthma
}

\author{
Brittany M. Salter, Xiaotian Ju and Roma Sehmi * \\ CardioRespiratory Research Group, Department of Medicine, McMaster University, \\ Hamilton, ON L8N 3Z5, Canada; brittmsalter@gmail.com (B.M.S.); jux@mcmaster.ca (X.J.) \\ * Correspondence: sehmir@mcmaster.ca; Tel.: +1-905-525-9140 (ext. 22963)
}

Citation: Salter, B.M.; Ju, X.; Sehmi, R. Eosinophil Lineage-Committed Progenitors as a Therapeutic Target for Asthma. Cells 2021, 10, 412. https://doi.org/10.3390/ cells10020412

Academic Editor: Stephane Esnault

Received: 24 January 2021

Accepted: 13 February 2021

Published: 16 February 2021

Publisher's Note: MDPI stays neutral with regard to jurisdictional claims in published maps and institutional affiliations.

Copyright: (C) 2021 by the authors Licensee MDPI, Basel, Switzerland. This article is an open access article distributed under the terms and conditions of the Creative Commons Attribution (CC BY) license (https:// creativecommons.org/licenses/by/ $4.0 /)$.

\begin{abstract}
Eosinophilic asthma is the most prevalent phenotype of asthma. Although most asthmatics are adequately controlled by corticosteroid therapy, a subset (5-10\%) remain uncontrolled with significant therapy-related side effects. This indicates the need for a consideration of alternative treatment strategies that target airway eosinophilia with corticosteroid-sparing benefits. A growing body of evidence shows that a balance between systemic differentiation and local tissue eosinophilopoietic processes driven by traffic and lung homing of bone marrow-derived hemopoietic progenitor cells (HPCs) are important components for the development of airway eosinophilia in asthma. Interleukin (IL)-5 is considered a critical and selective driver of terminal differentiation of eosinophils. Studies targeting IL-5 or IL-5R show that although mature and immature eosinophils are decreased within the airways, there is incomplete ablation, particularly within the bronchial tissue. Eotaxin is a chemoattractant for mature eosinophils and eosinophil-lineage committed progenitor cells (EoP), yet anti-CCR3 studies did not yield meaningful clinical outcomes. Recent studies highlight the role of epithelial cell-derived alarmin cytokines, IL-33 and TSLP, (Thymic stromal lymphopoietin) in progenitor cell traffic and local differentiative processes. This review provides an overview of the role of EoP in asthma and discusses findings from clinical trials with various therapeutic targets. We will show that targeting single mediators downstream of the inflammatory cascade may not fully attenuate tissue eosinophilia due to the multiplicity of factors that can promote tissue eosinophilia. Blocking lung homing and local eosinophilopoiesis through mediators upstream of this cascade may yield greater improvement in clinical outcomes.
\end{abstract}

Keywords: eosinophils; eosinophil progenitors; interleukin-5; epithelial-derived cytokines; eosinophilopoiesis

\section{Introduction}

Asthma is a chronic airways disease clinically characterized by reversible airflow obstruction, airway hyperresponsiveness (AHR), and inflammation, affecting more than 334 million people worldwide [1-4]. Over $80 \%$ of asthma-related deaths occur in low-and lower-middle income countries, indicating that treatment and effective management of asthma saves lives. The most common phenotype of asthma is eosinophilic asthma that is effectively managed by corticosteroid therapy [1-3]. However, a small proportion (5-10\%) of patients continue to have symptoms and persistent eosinophilia, despite high-dose oral corticosteroid therapy with substantial treatment-related side effects, and it accounts for the majority of the socio-economic and healthcare burden of asthma [4]. Therefore, exploring alternative treatment strategies is warranted. In this review, we will discuss the evidence for hematopoietic processes in eosinophilic asthma and the effect of various therapeutic targets on eosinophil levels and asthma management.

\section{Identification and Enumeration of Hematopoietic Progenitor Cells}

Under steady-state conditions, hematopoiesis primarily occurs in hematogenous sites within the bone marrow (BM), which are influenced by resident stromal cells-derived 
signals that maintain progenitor cells at various stages of lineage commitment. Hematopoietic progenitor cells (HPCs) are pluripotent stem cells with the capacity to self-renew and differentiate into mature blood cells. These cells are identified by surface expression of the stage-specific antigen CD34, which is a monomeric transmembrane O-sialylated glycophosphoprotein [5]. CD34 is highly expressed on primitive cells early in differentiation and progressively decreases with maturation, becoming absent on terminally differentiated cells [6]. CD34 is present on eosinophil progenitors (EoP) but not eosinophils [7]. The common myeloid progenitor gives rise to EoP, which are identified as $\mathrm{CD} 34^{+}$cells that co-express the interleukin (IL)-5 receptor alpha (IL-5R $\alpha$ ) [8,9]. The IL-5R is comprised of a unique cytokine binding $\alpha$ chain and common signaling $\beta$ chain, which is shared with IL-3 and Granulocyte-macrophage colony-stimulating factor, also known as colonystimulating factor (GM-CSF). The up-regulation of IL-5R $\alpha$ on HPC occurs at an early stage in eosinophil development and denotes eosinophil lineage commitment [8-10]. Progenitor cells can be enumerated by flow cytometry or in semi-solid cultures as eosinophil/basophil colony-forming units (Eo/B-CFU) [11]. The assessment of phenotypic changes in eosinophil progenitor cells and maturing eosinophils in the bone marrow of normal subjects is detailed elsewhere [12]. The complex interplay between growth factors, cytokines, and transcription factors (TFs) controls eosinophilopoiesis, which is detailed below.

\section{Regulation of Eosinophilopoiesis}

\subsection{Transcription Factors and Eosinophil Lineage Commitment}

Controlled sequential and transient expression of unique fate-determining TFs determines the lineage commitment of primitive pluripotent progenitor cells (Figure 1). TFs that promote eosinophil lineage-commitment include members of the globin transcription factor (GATA) family, where GATA-binding factor-1 (GATA-1) and GATA-binding factor-2 (GATA-2) expression are known to regulate eosinophil differentiation [13]. Studies show that although GATA-1-deficient mice have reduced fetal liver levels of EoP, GATA-2 maintains an instructive capacity comparable with GATA-1 in vitro and may compensate for GATA-1 deficiency in vivo [14]. Quantitative changes in GATA-1 expression alter HPC commitment, where moderate expression promotes eosinophil-lineage commitment while higher levels are inhibitory. Other TFs, including friend of GATA-1 (FOG-1) and interferon regulatory factor 8 (IRF8), regulate Gata1 expression. FOG-1 is highly expressed by HPCs, acts to antagonize GATA-1, and must be down-regulated for eosinophil differentiation to proceed [15-17]. In contrast, loss of IRF8 expression attenuates EoP frequency and Gata1 expression [18].

EoP express high levels of the TF CAAT/enhancer binding protein alpha (C/EBP $\alpha)$ [19-21]. The enforced expression of C/EBP $\alpha$ in HPC promotes eosinophil and neutrophil development [22] and C/EBP $\alpha$-deficiency in mice results in the attenuation of these cells [23]. $\mathrm{C} / \mathrm{EBP} \alpha$ expression levels impact differentiation, whereby high levels increase neutrophil development at the expense of eosinophils [24]. The specific order of GATA and C/EBP $\alpha$ expression is critical for eosinophil commitment [25]. Enforced expression of GATA-1 or GATA-2 in an already C/EBP $\alpha$-expressing progenitor cell results in eosinophil lineagecommitment, whereas GATA-2 expression prior to C/EBP $\alpha$ leads to basophil development. Additional isoforms of the C/EBP control eosinophil developmental stages. Low levels of activator C/EBP $\varepsilon$ isoforms are expressed in HPCs and increase during IL-5-induced differentiation, whereas repressor isoforms are present during later stages of maturation [26]. Deficiency in C/EBP $\varepsilon$ results in failed eosinophil maturation, indicating the critical role of these isoforms in regulating eosinophilopoiesis [27]. 


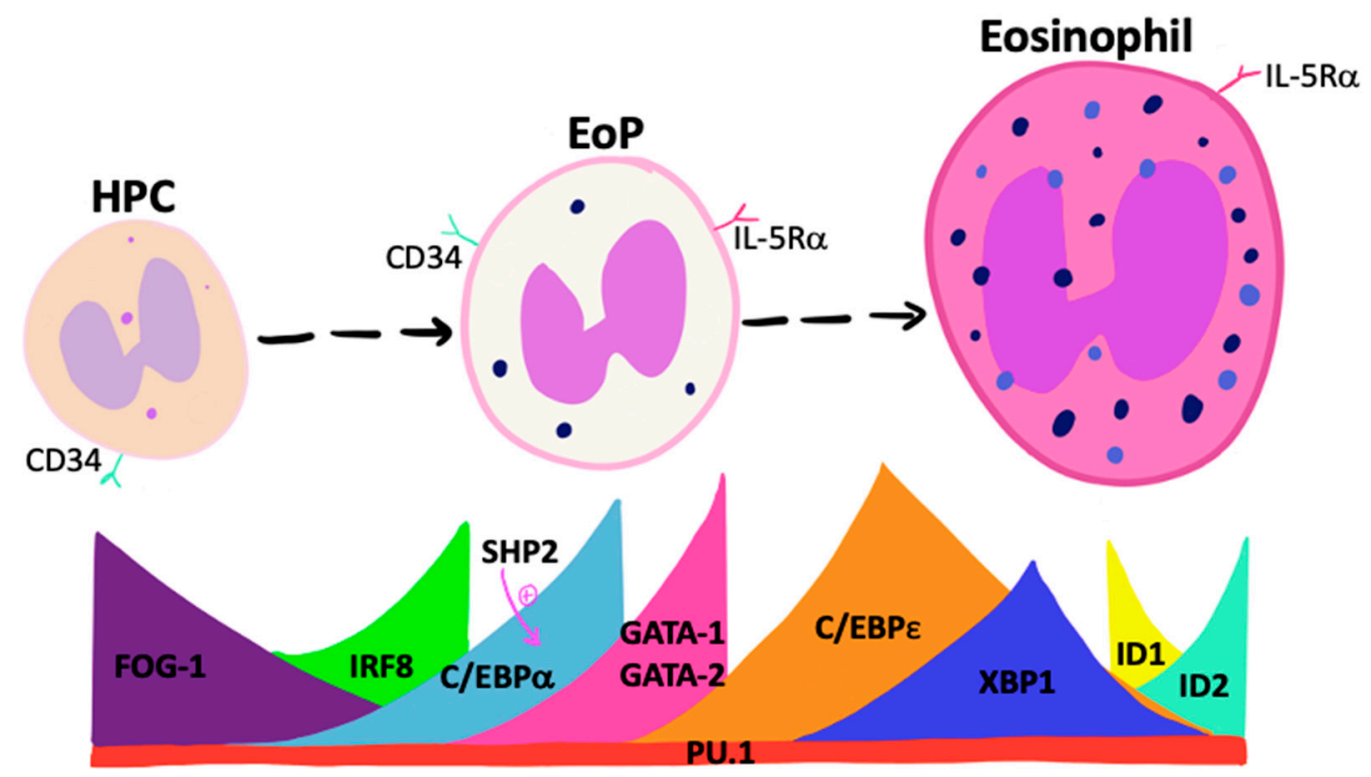

Figure 1. Transcription factors that instruct eosinophil differentiation. A number of transcription factors control eosinophil-lineage commitment and differentiation to mature eosinophils. A decline in FOG-1 and increased IRF8 up-regulates $C / E B P \alpha$, with subsequent GATA-1/GATA-2 expression. Collective IRF8, PU.1, $\mathrm{C} / \mathrm{EBP} \alpha$, and $\mathrm{C} / \mathrm{EBP} \varepsilon$ expression results in eosinophil-lineage commitment, followed by collaboration between C/EBP $\varepsilon$, PU.1, GATA-1, and GATA-2 for progression to mature eosinophils. XBP1 and balanced ID1/ID2 expression allows for eosinophil granule protein synthesis and survival. Abbreviations: $\mathrm{C} / \mathrm{EBP} \alpha=\mathrm{CAAT} /$ enhancer binding protein alpha; $\mathrm{C} / \mathrm{EBP}=\mathrm{CAAT} /$ enhancer binding protein epsilon; $\mathrm{EoP}=$ Eosinophil progenitor; FOG-1 = Friend of GATA-1; GATA-1 = Globin transcription binding factor-1; HPC = Hematopoietic progenitor cells; ID1 = Inhibitor of DNA-binding proteins 1; ID2 = Inhibitor of DNA-binding proteins 2; IL-5R $\alpha=$ Interleukin-5 receptor alpha; IRF8 = Interferon regulatory factor 8.

The TF, $\mathrm{X}$-box binding protein 1 (XBP1) is involved in unfolded protein responses triggered by endoplasmic reticular stress during cellular differentiation. In response to this stress, Xbp1 mRNA is spliced by Inositol-requiring enzyme $1 \alpha$ (IRE1 $\alpha)$, followed by the translation of XBP1 [28]. Accumulation of spliced Xbp1 mRNA is only detected in precursor and not mature eosinophils. The loss of Xbp1 expression in precursor populations results in an attenuation of eosinophil maturation and a lower frequency of EoP caused by the dysfunctional post-translational maturation of secondary granule proteins, including major basic protein and eosinophil peroxidase. Although XBP1 is not necessary for eosinophillineage commitment, it is an important survival factor for EoP and is critical for successful eosinophil maturation [28]. A human equivalent of this TF has not been reported to date but may provide an important therapeutic target for controlling eosinophilia.

The TF PU.1 is essential in myeloid development. The expression of PU.1 increases gradually throughout HPC development and remains constant during terminal differentiation [29]. The disruption of PU.1 expression causes defective granulocyte terminal differentiation, with an absence of functionally mature neutrophils and eosinophils. Gene expression analysis of PU.1-deficient fetal liver cells has shown the expression of granule proteins but little IL-5r $\alpha$ expression, suggesting that PU.1 is important but not essential for eosinophil commitment [30]. Recent studies implicate the Tribbles pseudokinase family (Trib) in controlling eosinophil-lineage commitment. Mice with germline deletion of Trib1 lack eosinophils and have greater numbers of neutrophils [24]. Trib1 expression suppresses neutrophil programing in lineage-committed EoP in response to IL-5 [31]. Trib1 regulates eosinophilopoiesis through the suppression of $\mathrm{C} / \mathrm{EBP} \alpha$, thereby blocking neutrophil differentiation. In addition, the tyrosine phosphatase, Src homology 2 domain-containing phosphatase 2 (SHP2), stimulates $C / E B P \alpha$ expression to regulate cytokine-dependent granu- 
lopoiesis, indicating that this TF may be a critical regulator of eosinophil differentiation [32]; the blockade of SHP2 inhibits eosinophilopoiesis [33].

The inhibitor of DNA-binding proteins (ID) is a family of negative transcriptional regulators, and ID2 is up-regulated during eosinophil maturation. The ectopic expression of ID2 in human HPC results in increased mature eosinophils but no change in frequency of early precursors [34]. On the other hand, ID1, an inhibitor of terminal eosinophil maturation, declines through the differentiative process [34]. These findings suggest that ID2 enhances terminal differentiation, whereas ID1 is inhibitory, and as such, a certain ratio of expression of ID proteins is required for eosinophilopoiesis.

In summary, eosinophil lineage commitment occurs when HPC sequentially express $\mathrm{C} / \mathrm{EBP} \alpha, \mathrm{C} / \mathrm{EBP} \varepsilon$, IRF8, and PU.1, along with declining FOG-1 and increases in GATA1/GATA-2 expression. Furthermore, data are suggestive of a delicate interplay between relative ratios and sequence of expression of various TFs during differentiation. Targeting specific TFs may provide effective therapeutic avenues for controlling tissue-specific eosinophilopoiesis, although this remains to be demonstrated in human disease (Figure 1).

\subsection{Eosinophilopoietic Factors}

Growth factors such as, IL-5, IL-3, and GM-CSF all participate in eosinophilopoiesis. In turn, the interaction of IL-5 and IL-5R $\alpha$ expressed by EoP mediates the terminal differentiation and growth of progenitor cells, with a resultant priming of activation and survival of mature eosinophils [35]. However, IL-5-deficient mice retain homeostatic levels of eosinophils, suggesting that other factors support eosinophilopoiesis [36,37]. Additional factors, including IL-3 and GM-CSF, mediate effects via IL-3R $\alpha$ and GM-CSFR $\alpha$, driving early stages of differentiation, whereas the $\beta$-common chain mediates cell signaling by all three eosinophilopoietic cytokines.

More recently, epithelial-derived alarmin cytokines have been implicated in promoting eosinophil differentiation either directly or indirectly. The triad of alarmins, including IL-25, IL-33, and TSLP, is produced by airway epithelium in response to environmental and microbial stimuli. The eosinophilopoietic potential of TSLP was first demonstrated in humans using cord-derived CD $34^{+}$cells, where TSLP stimulated the growth of Eo/BCFU in 14-day methylcellulose cultures, which was enhanced in the presence of IL-3 and $\mathrm{TNF} \alpha$ [38]. Similarly, the outgrowth of Eo/B-CFU in cultures of progenitor cells with bronchial epithelial cell-derived supernatants from severe asthmatics was reported and shown to be attenuated by TSLP blockade [39]. Furthermore, recombinant human TSLP, at picogram levels, stimulated the formation of Eo/B-CFU, with additive effects when combined with IL-5, in vitro. At the mRNA level, a synergistic increase in GATA-2 and $\mathrm{C} / \mathrm{EBP} \alpha$ in $\mathrm{CD} 34^{+}$cells were detected in the presence of TSLP and IL-5, indicating that TSLP can act either alone or in concert with traditional eosinophilopoietins to promote eosinophilopoiesis [39].

Mice deficient in IL-33 and the IL-33 receptor, ST2, have reduced peripheral blood (PB) eosinophils at baseline [40,41]. The administration of exogenous IL-33 increased BM and PB eosinophils in wild-type mice, IL-33 KO but not ST2 KO mice, and this effect was inhibited by anti-IL-5 treatment [40]. Although ST2 and IL-33 KO mice have significantly reduced eosinophil numbers, BM-derived progenitor cells cultured with IL-5 from these mice differentiate into eosinophils, suggesting that IL-5-driven eosinophilopoiesis can occur in the absence of IL-33 [42]. Thus, IL-33 may promote eosinophilopoiesis indirectly by stimulating IL- 5 production by either $\mathrm{CD} 34^{+}$cells [43] or accessory immune cells. In line with this, Boberg et al. reported that in mice challenged with house dust mite (HDM), an increase in group 2 innate lymphoid cells (ILC2) expressing ST2 was observed and these cell numbers correlated with EoP numbers [41]. The combination of HDM and IL-33 directly induced IL-5 production from BM ILC2 but not T cells to drive eosinophil differentiation. Additionally, IL-33 is postulated to up-regulate IL-5R $\alpha$ expression, leading to eosinophil lineage commitment via an ST2-dependent pathway [40,42]. Other studies report that GATA-1 and GATA-2 can up-regulate ST2 expression through GATA binding 
sites upstream of the ST2 promoter, suggesting that IL-33 may indeed be involved in eosinophil differentiation [44]. With respect to human studies, although CD34 ${ }^{+}$cells express ST2, it remains unknown whether IL-33 can induce eosinophilopoiesis $[43,45]$. Studies have shown that the eosinophil clonogenic capacity of bronchial epithelial cellderived supernatants from severe asthmatics is increased compared to normal and mild asthmatics, and this activity can be inhibited by TSLP but not IL-33 blockade [39]. It is possible that other airway structural cells, such as smooth muscle cells may be greater producers of IL-33 that could drive local eosinophilopoiesis within the lung, although this requires further investigation.

Lastly, with respect to IL-25, HPC and EoP express the receptor for IL-25 (IL-17RB) [46] and IL-25 can promote HPC expansion and contribution to type 2 inflammation in mice [47,48]. To date, no studies have reported either the direct or indirect effects of IL-25 on human eosinophilopoiesis, although priming effects of EoP migration have been reported [46].

With respect to cysteinyl leukotrienes (CysLT), similar to leukotriene D4 (LTD ${ }_{4}$, enhances GM-CSF- and IL-5-stimulated BM Eo/B-CFU growth, which can be attenuated by CysLT1 receptor antagonism [49]. Importantly, $\mathrm{LTD}_{4}$ does not induce the growth of Eo/B-CFU alone but in combination with IL-5/GM-CSF. This suggests that leukotrienes behave as co-factors of eosinophilopoiesis. In addition, chemokines such as eotaxin and regulated upon activation, normal T cell expressed and presumably Secreted (RANTES), alone or in combination with IL-5, can induce eosinophil differentiation from cord blood $\mathrm{HPC}$, although this was not seen in cultures of $\mathrm{CD} 34^{+}$cells from $\mathrm{PB}$ and $\mathrm{BM}$ of asthmatic subjects [50].

Collectively, cytokines and chemokine growth factors control lineage commitment and eosinophil maturation; further clarification is required for the tissue-specific effects of these factors and their role in homeostasis compared to disease states.

\section{Hematopoietic Processes in Eosinophilic Asthma}

The differentiation of HPC was traditionally thought to be restricted to peripheral hematogenous sites such as the BM; however, accumulating evidence suggests that progenitor cells trafficking to mucosal tissue sites of type 2 inflammation may contribute via in situ differentiative processes to local eosinophilia. Baseline cross-sectional studies initially showed that HPC $\left(\mathrm{CD} 34^{+} \mathrm{CD} 45^{+}\right.$cells) are increased in the BM and PB of atopics compared to healthy subjects [51]; the greatest number of precursor cells was detected in severe compared to mild asthmatics and non-asthmatic controls, correlating with serum IL-5 and GM-CSF levels [52]. In a baseline cross-sectional study, PB HPC from atopic or atopic asthmatics differentiated into greater numbers of Eo/B-CFU in the presence of IL-5 compared to healthy controls $[51,53]$. These numbers increased further in dual responder asthmatics following an asthma exacerbation [54]. The selective increase in Eo/B-CFU was also observed in asthmatic subjects undergoing stepwise withdrawal of inhaled corticosteroids until a mild exacerbation of symptoms occurred. In addition, following an inhaled-allergen (Ag) challenge, circulating Eo/B-CFU are increased $24 \mathrm{~h}$ post-Ag in dual responders but not early responder asthmatics [55]. Gauvreau et al. expanded on these findings to show that atopic individuals have higher HPC numbers expressing GM-CSF in blood compared to healthy controls, and atopic asthmatics challenged showed increased outgrowth of Eo/B-CFU growth with GM-CSF expression $24 \mathrm{~h}$ post-Ag [56]. This suggests that GM-CSF expression by HPC may provide an autocrine stimulus to enhance eosinophil differentiation. Additional studies have enumerated progenitor cells in the bronchial mucosa and reported that EoP (identified as CD $34^{+} \mathrm{IL}-5 \mathrm{R} \alpha \mathrm{mRNA}^{+}$cells) are increased in asthmatics compared to non-asthmatic controls and that these cells correlate with the level of airway dysfunction [35]. 
Eosinophil-lineage committed progenitor cells identified as $\mathrm{CD} 45^{+} \mathrm{CD} 34^{+} \mathrm{IL}-5 \mathrm{R} \alpha^{+}$cells by flow cytometry have been shown to be increased in the BM $24 \mathrm{~h}$ post-Ag challenge in mild asthmatics, with associated PB and sputum eosinophilia, and the development of AHR [8]. Similarly, Kuo et al. showed that circulating HPC express surface IL-5R $\alpha$ and intracellular IL-5, with greater expression in asthmatics compared to healthy controls at baseline [57]. Thus, the concomitant expression of intracellular IL-5 and extracellular IL-5R $\alpha$ on HPC indicates a potential autocrine loop that could drive eosinophilopoiesis [58]. With respect to disease severity, a 10-fold greater frequency of EoP has been reported in the sputum of severe prednisone-dependent asthmatics compared to mild asthma despite comparable numbers in PB [59]. This suggests that an exaggerated eosinophilopoietic environment may exist in the airways of eosinophilic severe asthmatics. Furthermore, EoP from severe asthmatics demonstrate a greater outgrowth of Eo/B-CFU in response to similar concentrations of IL-5 and a significantly greater spontaneous clonogenic capacity when cultured with diluent alone compared to EoP from mild asthmatics, supporting the potential for autocrine cytokine generation promoting eosinophilopoiesis in more severe disease [59]. Although not definitive, these findings support the proposal that in situ eosinophilopoiesis may contribute to the local expansion of eosinophils in the airways of severe eosinophilic asthmatics. In support of this, Cameron et al. showed that the addition of allergen or IL-5 to nasal explants from ragweed sensitive allergic rhinitics resulted in a decline in EoP numbers and concurrent increase in mature eosinophils within 6-24 h of culture which was inhibited by IL-5 blockade [60]. Similarly, another study has reported that following inhalation of IL-5, CD $34^{+} / \mathrm{IL}-5 \mathrm{R} \alpha \mathrm{mRNA}^{+}$cells decline within the bronchial mucosa of asthmatics $24 \mathrm{~h}$ post-inhalation, with an associated increase in eosinophils [61], indirectly supporting the view that EoP give rise to mature eosinophils within the lung during allergic inflammatory responses in an IL-5-dependent manner.

Accumulating evidence supports the hypothesis that following exposure to Ag, progenitor cells egress from BM and traverse to the airways where they undergo in situ eosinophilopoiesis. This process is complex and regulated by numerous mediators within both the systemic and local tissue environment (Figure 2). Moving forwards, it is important to determine the predominant mechanisms driving the eosinophilopoietic processes to develop novel targets for asthma. The trafficking of progenitor cells is further supported by increased CCR $3^{+} \mathrm{HPC}$ numbers within the BM $24 \mathrm{~h}$ post-Ag challenge, which is associated with increased migrational response to eotaxin-1 (CCL11) but decreased responsiveness to tissue-retentive mediators such as stromal cell-derived factor $1 \alpha$ (SDF- $1 \alpha)$, in vitro [62-64]. It is postulated that reduced retentivity mediated by decreased response to SDF- 1 and increased response to CCL-11, mediates progenitor cell egress from the BM to the periphery during allergen-induced asthmatic responses. The effects of eotaxin- 2 and eotaxin- 3 were not assessed in these studies.

Schwartz et al. reported increased PB EoP in the pediatric asthma population, which negatively correlated with asthma control [65]. This suggests that a decline in PB EoPs may be associated with loss of asthma control due to the recruitment of cells into airway tissue. It remains unclear whether EoP contributes to this process simply as precursors of mature eosinophils or as a source of pro-inflammatory cytokines [43]. 


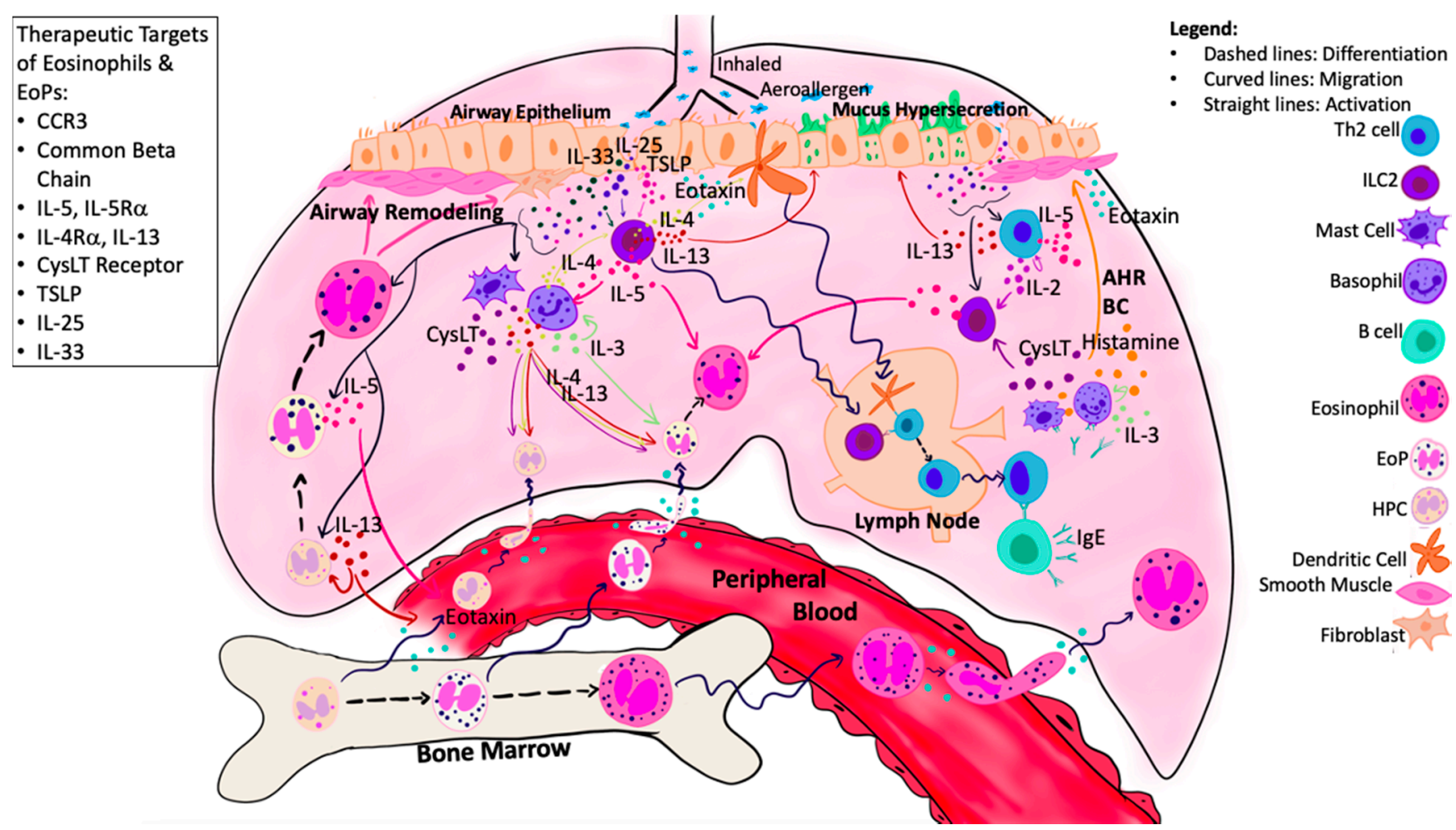

Figure 2. Eosinophilopoietic processes in asthma-damaged airway epithelial cells release alarmins, which activate local ILC2s, resulting in release of type 2 cytokines, including IL-5, IL-4, and IL-13. Growth factors (IL-5/IL-3/GM-CSF) produced by local effector cells and airway epithelium, in combination with alarmins, induce in situ eosinophilopoiesis. The migration of HPCs, EoPs, and eosinophils is mediated by local and systemic chemo-attractants, including eotaxin, which is enhanced by local CysLTs, alarmin cytokines, and type 2 cytokines. Within the airways, eosinophils contribute to tissue damage and airway remodeling through the production of granule proteins. Numerous targets have been identified that may attenuate both eosinophil and EoP activity, including CCR3, IL-5, IL-4/IL-13, common beta chain, CysLT receptor, and alarmins. Abbreviations: ASM = Airway smooth muscle; AHR = Airway hyperresponsiveness; $\mathrm{BC}=$ Bronchoconstriction; CysLT = Cysteinyl leukotrienes; Eo = Eosinophil; EoP = Eosinophil Progenitor Cell; HPCs = Hematopoietic progenitor cells; ILC2 = Group 2 innate lymphoid cells.

\section{Targets of Airway Eosinophilopoietic Processes in Asthma}

Evidence points toward local in situ hematopoiesis within the airways, leading to a significant contribution to eosinophilic inflammation. Targeting the underlying mechanisms that drive local eosinophilopoiesis poses as a therapeutic avenue to modulate airway eosinophilia. Although IL-5 has been identified as a major driver of eosinophil differentiation, many other mediators may contribute to this process. Here, we will discuss the proposed targets of eosinophilopoiesis in asthma and results from clinical trials; specific targets are summarized in Table 1.

\subsection{Anti-Common Beta Chain Therapy}

The triad of growth factors, including IL-5, IL-3, and GM-CSF, has the potential to drive eosinophilopoiesis, and as such, therapies have been developed which targt the common signaling $\beta$ chain of the IL-5/IL-3/GM-CSF receptors. A study with a $\beta$ chain monoclonal antibody (mAb), CSL 311, was assessed for its ability to affect eosinophilopoiesis.

With respect to in vitro experiments, CSL 311 reduced the growth of BM- and PBderived Eo/B-CFU that were incubated with IL-5/IL-3/GM-CSF pre- and $24 \mathrm{~h}$ post-Ag challenge in mild asthmatics [66]. In clinical studies with asthmatics, it was shown that treatment with an anti-sense TPI ASM 8 ( $4 \mathrm{mg}$ bid and $8 \mathrm{mg}$ o.d. inhaled for 4 days) directed against the $\beta$ common chain and CCR3, attenuated Ag-induced airway eosinophilia $[66,74]$ 
as well as $\mathrm{CCR}^{+} \mathrm{HPC}$ and EoP numbers [67]. In addition, drug treatment significantly attenuated $\mathrm{FEV}_{1}$ during the early and late asthmatic response and it improved the $\mathrm{MCh}$ $\mathrm{PC}_{20} 24$ post- $\mathrm{Ag}$ (Table 1). These findings suggest that dual blockade of the $\beta$ chain and CCR3 results in a reduction of not only eosinophilopoiesis but also lung trafficking of mature and eosinophil precursor cells. As convincing as these results are, there was an incomplete ablation of airway eosinophils and EoP, underscoring the concept of additional pathways contributing to eosinophilic lung inflammation.

Table 1. Therapeutic targets of both mature and immature eosinophils.

\begin{tabular}{|c|c|c|c|c|c|}
\hline Study & Therapeutic Agent & Subjects & $\begin{array}{l}\text { Effects on Mature } \\
\text { Eosinophils }\end{array}$ & $\begin{array}{c}\text { Effects on } \\
\text { Eosinophil } \\
\text { Progenitors }\end{array}$ & $\begin{array}{c}\text { Other } \\
\text { Inflammatory } \\
\text { Outcomes }\end{array}$ \\
\hline $\begin{array}{l}\text { Pageau et al. } 2011 \\
{[66]}\end{array}$ & $\begin{array}{l}\text { TPI ASM8 ( } 4 \mathrm{mg} \text { bid, } 8 \mathrm{mg} \\
\text { o.d. inhaled for } 4 \mathrm{~d}) \\
\text { Anti-sense oligonucleotide } \\
\text { against common } \beta \text { chain } \\
\text { and CCR3 }\end{array}$ & MA & Reduced SP Eos & $\begin{array}{c}\text { Reduced SP } \\
\text { CCR3 }^{+} \mathrm{HPC} \text { and EoP }\end{array}$ & $\begin{array}{l}\text { Reduced SP ECP } \\
\text { levels }\end{array}$ \\
\hline $\begin{array}{l}\text { Imaoka et al. } 2011 \\
\text { [67] }\end{array}$ & $\begin{array}{l}\text { TPI ASM8 (4 mg bid or } 8 \\
\text { mg o.d. inhaled, for } 4 \mathrm{~d}) \\
\text { Anti-sense oligonucleotide } \\
\text { against common } \beta \text { chain } \\
\text { and CCR3 }\end{array}$ & MA & $\begin{array}{l}\text { Reduced SP Eos at } 7 \\
\mathrm{~h} \text { and } 24 \mathrm{~h} \text { post-Ag }\end{array}$ & $\begin{array}{l}\text { Reduced SP } \\
\text { CCR } 3^{+} \text {HPC at pre- } \\
\text { and } 24 \text { h post-Ag } \\
\text { No effect on total } \\
\text { HPC }\end{array}$ & Not reported \\
\hline $\begin{array}{c}\text { Panousis et al. } 2016 \\
{[68]}\end{array}$ & $\begin{array}{l}\text { CSL } 311(100 \mu \mathrm{g} / \mathrm{mL}) \\
\text { Common } \beta \text { chain mAb }\end{array}$ & $\mathrm{HC}$ and MA & $\begin{array}{l}\text { Reduced PB } \\
\text { Eos survival }\end{array}$ & $\begin{array}{l}\text { Decreased BM and } \\
\text { PB Eo/B-CFU pre- } \\
\text { and } 24 \text { h post-Ag }\end{array}$ & Not reported \\
\hline $\begin{array}{l}\text { Neighbour et al. } 2013 \\
\text { [69] }\end{array}$ & $\begin{array}{l}\text { GW766944 (300 mg PO bid } \\
\text { for 10d) CCR3 Antagonist }\end{array}$ & MA & $\begin{array}{l}\text { No effect on PB or } \\
\text { SP Eos }\end{array}$ & $\begin{array}{l}\text { No effect on PB or } \\
\text { SP EoP }\end{array}$ & Not reported \\
\hline $\begin{array}{l}\text { Menzies-Gow et al. } \\
2003 \text { [70] }\end{array}$ & $\begin{array}{c}\text { Mepolizumab (750 mg IV at } \\
\text { 1, 4, } 8 \text { weeks) Anti-IL-5 } \\
\text { mAb }\end{array}$ & MA & $\begin{array}{l}\text { Reduced BM and } \\
\text { PB Eos }\end{array}$ & $\begin{array}{l}\text { Reduced EoP in } \\
\text { bronchial mucosa } \\
\text { No effect on BM or } \\
\text { PB EoP or Eo/B-CFU }\end{array}$ & Not reported \\
\hline Sehmi et al. 2016 [59] & $\begin{array}{c}\text { Mepolizumab (100 mg q4 } \\
\text { weeks SC for } 10 \text { weeks) } \\
\text { Anti-IL-5 mAb }\end{array}$ & $\begin{array}{l}\text { SA }(>3 \% \text { SP Eos, } \\
>300 \text { cells } / \mu \mathrm{L})\end{array}$ & $\begin{array}{l}\text { Reduced PB Eos } \\
\text { No effect on SP Eos }\end{array}$ & $\begin{array}{l}\text { Increased PB EoP } \\
\text { No effect on SP EoP }\end{array}$ & -Not reported \\
\hline $\begin{array}{c}\text { Mukherjee et al. } 2018 \\
\text { [71] }\end{array}$ & $\begin{array}{c}\text { Reslizumab }(3.0 \mathrm{mg} / \mathrm{kg} \text { IV } \\
\text { q4 weeks, total of } 16 \text { weeks }) \\
\text { Anti-IL- } 5 \mathrm{mAb}\end{array}$ & $\begin{array}{l}\text { SA }(>3 \% \text { SP Eos, } \\
>300 \text { cells } / \mu \mathrm{L})\end{array}$ & $\begin{array}{l}\text { Reduced PB and } \\
\text { SP Eos }\end{array}$ & $\begin{array}{l}\text { Reduced PB and SP } \\
\text { HPC, PB EoP } \\
\text { No effect on SP EoP }\end{array}$ & Not reported \\
\hline Sehmi et al. 2018 [72] & $\begin{array}{c}\text { Benralizumab ( } 30 \mathrm{mg} \mathrm{SC} \mathrm{q4} \\
\text { weeks for } 28 \text { weeks) } \\
\text { Anti-IL-5R } \alpha \text { mAb }\end{array}$ & $\begin{array}{l}\text { SA }(>3 \% \text { SP Eos, } \\
>300 \text { cells } / \mu \mathrm{L})\end{array}$ & $\begin{array}{l}\text { Reduced PB and } \\
\text { SP Eos }\end{array}$ & $\begin{array}{l}\text { Reduced PB EoP } \\
\text { Trend toward } \\
\text { decrease in SP EoP }\end{array}$ & Not reported \\
\hline $\begin{array}{l}\text { Parameswaran N } \\
\text { et al. } 2004 \text { [73] }\end{array}$ & $\begin{array}{c}\text { Pranlukast CysLT Receptor } \\
\text { Antagonist ( } 300 \mathrm{mg} \text { PO bid } \\
\text { for } 2 \text { weeks) }\end{array}$ & MA & $\begin{array}{l}\text { Reduced SP Eos pre- } \\
\text { and } 24 \mathrm{~h} \text { post-Ag } \\
\text { Reduced SP EG2+ } \\
\text { cells pre- and } 24 \mathrm{~h} \\
\text { post-Ag }\end{array}$ & $\begin{array}{l}\text { Reduced BM } \\
\text { Eo/B-CFU and } \\
\mathrm{CCR}^{+} \mathrm{HPC}\end{array}$ & $\begin{array}{l}\text { Trends for reduced } \\
\text { SP cells }+ \text { for IL-5 } \\
\text { Eotaxin and } \\
\text { RANTES } 24 \mathrm{~h} \\
\text { post-Ag }\end{array}$ \\
\hline
\end{tabular}

Abbreviations: $\mathrm{Ag}=$ Allergen; bid = Twice daily; $\mathrm{BM}=$ Bone marrow; CysLT = Cysteinyl Leukotriene; $\mathrm{d}=$ Days; ECP = Eosinophil cationic protein; EoP = Eosinophil progenitors; Eos = Eosinophils; Eo/B-CFUs = Eosinophil/Basophil-colony forming units; h = Hour; $\mathrm{HC}=$ Healthy controls; $\mathrm{HPC}=$ Hematopoietic progenitor cells; $\mathrm{MA}=$ Mild asthmatics; $\mathrm{mAb}=$ Monoclonal antibody; $\mathrm{PB}=$ Peripheral blood; $\mathrm{PO}=$ oral $; \mathrm{SA}=$ Severe asthmatics; $\mathrm{SC}=$ subcutaneous; $\mathrm{SP}=$ sputum.

\subsection{Anti-Migrational Responsiveness Therapy}

The trafficking of eosinophils and progenitor cells to the lungs is a key contributing process to airway eosinophilia. Preclinical studies in mice show that treatment with a CCR3 mAb can abolish eosinophil recruitment to the lungs [75]. However, similar studies in human asthma have not yielded similar findings. Treatment with an anti-CCR3 small molecular weight antagonist (GW766994 $300 \mathrm{mg}$, PO bid for 10 days) in mild-moderate asthmatics did not attenuate airway eosinophilia, EoP numbers, or cause any clinically relevant improvement in $\mathrm{FEV}_{1}$ [69]. A more recent study targeting CCR3 showed that pre-treatment with AXP1275 (50 mg PO o.d.) in mild asthmatics resulted in a trend toward reduced sputum eosinophils at $24 \mathrm{~h}$ post- $\mathrm{Ag}$ but no attenuation of AHR [76]. A recent 
study, with R321 (a CCR3 antagonist that self-assembles into nanoparticles and binds CCR3 directly), showed that treatment inhibits eosinophil lung homing and AHR in a murine model of asthma [77]. Overall, these findings raise the question as to whether additional chemo-attractants, other than the eotaxin family of cytokines (Eotaxin 1-3; CCL11, CCL24, and CCL-26, respectively) control eosinophil and EoP trafficking to the airways. A consideration from these studies is that the local eoisnophilopoietic process may not be affected by CCR3 antagonism, thus targeting processes in both trafficking to the airways and differentiation within the airways may have a more profound effect on airway eosinophilia.

\subsection{Anti-IL-5 Therapy}

Three mAbs targeting IL-5 activity have been approved for the treatment of eosinophilic asthma, including mepolizumab and reslizumab (bind directly to IL-5), and benralizumab (binds to the IL-5 and IL-5R $\alpha$ ). These agents cause a robust decline in PB eosinophilia, with an associated reduction in exacerbations and improved asthma control. Results from the various studies described below are summarized in Table 1.

Mepolizumab has the capacity to reduce eosinophil numbers across several body compartments, including BM, PB, and bronchial mucosa. However, the translation of reduced systemic or local airway eosinophilia into meaningful clinical outcomes varies between clinical trials [2,59,61,78-85]. Menzies-Gow et al., reported that treatment of mild asthmatics with mepolizumab $750 \mathrm{mg}$ IV (1, 4, 8 weeks) resulted in significantly decreased $\mathrm{BM}$ and $\mathrm{PB}$ eosinophils (70\% and 100\% respectively) but no significant effect on EoP enumerated by flow cytometry or methyl-cellulose culture [70,82]. A significant but partial attenuation of EoP (detected as CD $34^{+} \mathrm{IL}-5 \mathrm{R} \alpha \mathrm{mRNA}^{+}$cells) and mature eosinophils (52\% and $55 \%$, respectively) was detected in bronchial mucosa, indicating a partial role for IL-5 in driving eosinophilopoiesis in the lungs of mild asthmatics. Additional factors (IL-3 and GM-CSF) may contribute to driving eosinophilia in systemic hematogenous niches in these subjects. Studies in prednisone-dependent severe asthmatics (sputum eosinophils $>3 \%$ ) whose disease was postulated to be primarily driven by IL-5, reported that after 10 weeks of treatment with mepolizumab $100 \mathrm{mg}$ subcutaneous (SC), there was a rapid and sustained reduction in PB eosinophils, with an associated increase in EoP caused by the IL-5 blockade of terminal differentiation [59]. In contrast, there was no significant treatment effect on sputum eosinophils or EoP numbers in this small group study. A proposed explanation is that in situ eosinophilopoiesis may be the predominant process contributing to airway eosinophilia in severe asthma, and that SC administration did not provide adequate airway bioavailability of mepolizumab. To understand this further, Mukherjee et al. conducted a study to compare the efficacy of weight-adjusted reslizumab $3 \mathrm{mg} / \mathrm{kg}$ IV in severe asthmatics ( $>3 \%$ sputum; $>300$ cells $/ \mu \mathrm{L}$ eosinophils) previously treated with mepolizumab $100 \mathrm{mg}$ SC q4 weeks for at least 1 year [71]. Two infusions of placebo q4 weeks was followed by four infusions of reslizumab $3 \mathrm{mg} / \mathrm{kg}$ q4 weeks (16 weeks total). Reslizumab attenuated sputum and PB eosinophils by $91.2 \%$ and $87.4 \%$, respectively. Reslizumab reduced sputum and PB HPC numbers, along with PB EoP, but it had a limited effect on sputum EoP. Overall, IV reslizumab reduced systemic and local eosinophils, resulting in a clinically relevant improvement in $\mathrm{FEV}_{1}$ and symptom scores. Other studies report that reslizumab can reduce eosinophils across varying compartments, but progenitor cells were not outcome measures [86-93]. Nonetheless, although reslizumab looks promising for the reduction of circulating and local eosinophilia, treatment does not completely ablate mature or immature eosinophils, suggesting that additional factors, aside from IL-5, within the local airway environment can regulate in situ eosinophilopoiesis.

Clinical trials with benralizumab in mild asthma have shown that subsequent treatment results in a long-lasting reduction of eosinophils [94-96]. A Canadian sub-study of the phase III ZONDA trial reported that 28 weeks of treatment with benralizumab $30 \mathrm{mg}$ SC q4 weeks significantly attenuated $\mathrm{PB}$ and sputum eosinophils, and it similarly reduced PB EoP numbers in prednisone-dependent severe eosinophilic asthmatics ( $>3 \%$ sputum; 
$>300$ cells $/ \mu \mathrm{L}$ eosinophils) [72]. The number of IL-5-responsive PB Eo/B-CFU significantly decreased with treatment as did sputum EoP numbers, in contrast to the report with mepolizumab caused by benralizumab mediated antibody-dependent cell cytotoxicity of all IL-5R $\alpha$-expressing cells [72]. It is proposed that the effective attenuation of mature eosinophils as well as local EoP in the airways contributed to significant attenuation of sputum EoP. This was associated with a steroid sparing effect and improvement in asthma control, indicating that controlling local eoisnophilopoietic processes may be an important process by which airway eosinophils arise in severe eosinophilic asthmatics.

\subsection{Anti-IL-4/IL-13 Therapy}

IL-4 and IL-13 play a role in promoting type 2 inflammation through acting as chemoattractants for eosinophils and progenitor cells to the airways. Studies indicate that IL-4 and IL-13 can directly prime the migrational response of progenitor cells in vitro and that epithelial-derived alarmin cytokines (TSLP, IL-33, and IL-25) prime EoP migration by stimulating the autologous production of IL-4 and/or IL-13 [45,46]. The targeting of both IL-4 and IL-13 has been postulated as a novel treatment for asthma.

Dupilumab is an mAb that binds to the IL-4 receptor $\alpha$ chain and prevents the binding of both IL-4 and IL-13. Moderate to severe asthmatics ( $>3 \%$ sputum; $>300$ cells $/ \mu \mathrm{L}$ eosinophils) treated with dupilumab $300 \mathrm{mg}$ SC once weekly for 12 weeks had a significant reduction in exacerbations, serum eotaxin, and TARC levels, but no clear pattern of change in PB eosinophils [97]. Other studies have shown that dupilumab treatment causes a transient increase in PB eosinophils compared to placebo or corticosteroid treatment $[98,99]$. These findings suggest that the blockade of IL-4/IL-13 reduces eosinophil migration to local tissues, resulting in transient increases of PB eosinophils.

With respect to IL-13-targeted therapy, the treatment of uncontrolled asthmatics with the mAb lebrikizumab $37.5 \mathrm{mg}$ or $125 \mathrm{mg}$ SC q4 weeks for 52 weeks resulted in increased peripheral eosinophilia due to reduced migration to the airways $[100,101]$. Subsequent phase III trials did not show any reduction in asthma exacerbation; thus, the use of anti-IL13 agents has lost favor [101]. An explanation for this may be that the blockade of IL-13 alone is inadequate to achieve asthma control due to overlapping roles with IL-4.

These studies support the notion that IL-4/IL-13 signaling pathways can enhance the migration of mature and immature eosinophils and induce lung structural cells to produce the eotaxin family of cytokines. The blockade of IL-4/IL-13 results in attenuated lung trafficking of eosinophils and possibly EoP, although this has not been investigated to date. Further studies are required to better understand how the blockade of IL-4/IL-13 can affect local eosinophilopoietic processes and migration by assessing EoP numbers in the airways of patients receiving Dupilumab therapy.

\subsection{Anti-CysLT and PPAR Agonist Therapy}

CysLTs are important mediators that enhance eosinophil chemotaxis and survival as well as influence eosinophilopoiesis. Given that CysLTs can modulate both mature and immature eosinophil activity, several studies have looked at the efficacy of receptor blocking agents to treat asthma. In vitro stimulation with $\mathrm{LTD}_{4}$ can enhance Eo/B-CFU in the presence of IL-5 and GM-CSF, which can be reversed with montelukast [49]. Mild asthmatics treated with pranlukast $300 \mathrm{mg}$ PO bid for 2 weeks resulted in reduced sputum eosinophil counts pre- and $24 \mathrm{~h}$ post-Ag challenge compared to placebo [73]. Similar trends were seen for eotaxin and IL-5 levels. Pranlukast also significantly attenuated Ag-induced increases in IL-5-responsive Eo/B-CFU in BM and sputum CCR ${ }^{+}$HPC numbers (Table 1). These findings suggest that CysLT receptor antagonists decrease airway eosinophilia through blocking the migration of mature and immature eosinophils from the BM to the airways, and the eosinophilopoietic potential of progenitor cells.

Peroxisome proliferator-activated receptor (PPAR) agonists have been proposed as novel agents to reduce airway inflammation. Murine models of asthma have shown that PPAR agonists can inhibit airway eosinophilia and AHR [102]. With respect to human 
studies, Smith et al. demonstrated that in vitro treatment with rosiglitazone (PPAR gamma agonist) reduced Eo/B-CFU growth in the presence of IL-5 and IL-3 [103]. In 2017, a clinical trial assessed the effect of pioglitazone on prednisone-dependent severe asthma [104]. Patients were treated with pigolitazone $30 \mathrm{mg}$ PO daily for 2 weeks, followed by $45 \mathrm{mg}$ daily for 14 weeks. No difference was found regarding peripheral eosinophil counts or lung function and $14 \%$ of subjects experienced severe adverse events, resulting in drug discontinuation.

\subsection{Anti-Alarmin Therapy}

Alarmins have emerged as novel mediators of eosinophilic inflammation through directly activating ILC2 and $\mathrm{CD}^{+}{ }^{+} \mathrm{T}$ cells to produce type 2 cytokines. Alarmins can also directly or indirectly affect EoP activity, migration, and differentiation. Unfortunately, few studies have investigated the effect of blocking these cytokines on eosinophilopoietic processes in human asthma.

Initial animal studies have shown that TSLP blockade can inhibit Ag-induced type 2 inflammation, airway eosinophilia, and AHR [105-107]. Our own in vitro findings demonstrate that TSLP-mediated eosinophilopoietic activity in bronchial epithelial cell supernatants from severe asthmatics and that TSLP, alone, can stimulate Eo/B-CFU formation in 14-day methycellulose cultures enhanced by IL-5 [39]. Gauvreau et al. reported that treatment with an anti-TSLP mAb, AMG 157, $700 \mathrm{mg}$ IV q4 weeks for 12 weeks in mild asthma yielded a significant reduction in PB and sputum eosinophils at baseline and $24 \mathrm{~h}$ post-Ag challenge in mild asthmatics [108]. Similarly, a Phase IIb (PATHWAY) trial with tezepelumab (70 mg or $210 \mathrm{mg}$ q4 weeks or $280 \mathrm{mg}$ q2 weeks for 52 weeks) as add-on therapy in uncontrolled moderate-to-severe asthmatics showed persistent decreases in PB eosinophils and type 2 cytokines, associated with an improvement in annualized exacerbation rates and improvement in lung function [109]. These findings may be attributed to TSLP blockade attenuating eosinophilopoiesis; however, further detailed studies are required to assess this hypothesis.

IL-33 can induce eosinophilopoiesis and enhance EoP migration [41,45-47], suggesting that the blockade of the IL-33/ST2 axis may result in impaired airway eosinophilia. Murine models have shown that ST2 blockade or anti-IL-33 mAbs can reduce eosinophils and type 2 cytokines within BALF $[40,110,111]$. There are ongoing human clinical trials assessing the efficacy of anti-IL-33 mAbs to treat severe asthma and atopic dermatitis. A phase IIa clinical trial of etokimab $300 \mathrm{mg}$ IV in atopic dermatitis demonstrated a significant reduction in symptom and severity scores, along with reduced peripheral eosinophilia 29 days post-administration [112]. A phase IIa trial with etokimab $300 \mathrm{mg}$ IV in peanut allergy reported reduced type 2 cytokine levels and ST2 ${ }^{+} \mathrm{CD}^{+}{ }^{+} \mathrm{T}$ cells upon peanut-induced $\mathrm{T}$ cell activation compared to placebo [113]. However, this study did not report eosinophil counts. Interim analyses of a phase IIa study with etokimab $300 \mathrm{mg}$ IV in severe asthmatics (>300 cells / $\mu \mathrm{L}$ eosinophils) reported improvements in $\mathrm{FEV}_{1}$ at day 2 compared to placebo, which remained significant at day 64 [114]. Improvements in lung function were associated with reduced PB eosinophils by $31 \%$ and $46 \%$ at days 2 and 64, respectively. The finalized results of the asthma-related clinical trials will shed light on whether blockade of the IL-33/ST2 axis can affect eosinophilopoiesis and translate into clinically relevant outcomes.

With respect to IL-25, mouse models have shown that the administration of IL-25 results in increased AHR, type 2 inflammation, and airway eosinophilia [115-117], which can be reversed by the blockade of IL-25 [118,119]. To our knowledge, ABM125 is the only anti-IL-25 mAb currently in preclinical development, and more time will be needed to see how this agent affects human eosinophilia.

\section{Conclusions}

We have provided evidence that systemic and local eosinophilopoiesis are important contributing processes to airway eosinophilia in asthma. There is a complex interplay of surrounding mediators that influence EoP egress from BM, trafficking to the airways, and in 
situ eosinophilopoiesis (Figure 2). Understanding what signaling pathways can influence EoP is key to developing therapeutic targets for the attenuation of airway eosinophilia. As promising as anti-IL- 5 therapy is, there appears to be other underlying mediators independent of IL-5 that drive eosinophilopoiesis. A comparative analysis between these treatment strategies will help determine the most efficacious therapy for attenuating eosinophilic inflammation. There should be consideration for therapeutic agents that block multiple processes involved in airway eosinophilia, including mature and immature eosinophil migration, eosinophilopoiesis, and cell activation. Another novel approach may be to target ILC2, which are primarily activated by alarmin cytokines to produce copious amounts of IL-5 and IL-13. Uncontrolled ILC2 activity may be a key contribution to corticosteroid resistance in severe asthma. Thus, targeting these upstream cells may result in subsequent down-regulation in both mature and immature eosinophil activity. We propose that combined targeting of redundant pathways that control multiple functions of mature and immature eosinophils is necessary to ameliorate type 2 inflammation and create a more robust reduction in airway eosinophilia.

Funding: This research received no external funding.

Conflicts of Interest: The authors declare no conflict of interest.

\section{References}

1. Leuppi, J.D.; Salome, C.M.; Jenkins, C.R.; Anderson, S.D.; Xuan, W.; Marks, G.B.; Koskela, H.; Brannan, J.D.; Freed, R.; Andersson, M.; et al. Predictive Markers of Asthma Exacerbation during Stepwise Dose Reduction of Inhaled Corticosteroids. Am. J. Respir. Crit. Care Med. 2001, 163, 406-412. [CrossRef]

2. Green, R.H.; Brightling, C.E.; McKenna, S.; Hargardon, B.; Parker, D.; Bradding, P.; Wardlaw, A.J.P.I. Asthma Exacerbations and Sputum Eosinophil Counts: A Randomised Controlled Trial. Lancet 2002, 9347, 1715-1721. [CrossRef]

3. Lemière, C.; Ernst, P.; Olivenstein, R.; Yamauchi, Y.; Govindaraju, K.; Ludwig, M.S.; Martin, J.G.; Hamid, Q. Airway Inflammation Assessed by Invasive and Noninvasive Means in Severe Asthma: Eosinophilic and Noneosinophilic Phenotypes. J. Allergy Clin. Immunol. 2006, 118, 1033-1039. [CrossRef] [PubMed]

4. Barnes, P.J.; Adcock, I.M. Glucocorticoid Resistance in Inflammatory Diseases. Lancet 2009, 373, 1905-1917. [CrossRef]

5. Civin, C.I.; Strauss, L.C.; Brovall, C.; Fackler, M.J.O.; Schwartz, J.F.; Shaper, J.H. Antigenic Analysis of Hematopoiesis. III. A Hematopoietic Progenitor Cell Surface Antigen Defined by a Monoclonal Antibody Raised against KG-1a Cells. Information about Subscribing to The Journal of Immunology Is Online at: A Hematopoietic Progenito. J. Immunol. 1984, 133, 157-165. [PubMed]

6. Krause, D.S.; Fackler, M.J.; Civin, C.I.M.W. CD34: Structure, Biology, and Clinical Utility. Blood 1996, 87, 1-13. [CrossRef]

7. Sergejeva, S.; Johansson, A.K.; Malmhäll, C.; Lötvall, J. Allergen Exposure-Induced Differences in CD34+ Cell Phenotype: Relationship to Eosinophilopoietic Responses in Different Compartments. Blood 2004, 103, 1270-1277. [CrossRef]

8. Sehmi, R.; Wood, L.J.; Watson, R.; Foley, R.; Hamid, Q.; O’Byrne, P.M.; Denburg, J.A. Allergen-Induced Increases in IL-5 Receptor $\alpha$-Subunit Expression on Bone Marrow-Derived CD34+ Cells from Asthmatic Subjects: A Novel Marker of Progenitor Cell Commitment towards Eosinophilic Differentiation. J. Clin. Investig. 1997, 100, 2466-2475. [CrossRef]

9. Iwasaki, H.; Mizuno, S.; Mayfield, R.; Shigematsu, H.; Arinobu, Y.; Seed, B.; Gurish, M.F.; Takatsu, K.; Akashi, K. Identification of Eosinophil Lineage-Committed Progenitors in the Murine Bone Marrow. J. Exp. Med. 2005, 201, 1891-1897. [CrossRef]

10. Mori, Y.; Iwasaki, H.; Kohno, K.; Yoshimoto, G.; Kikushige, Y.; Okeda, A.; Uike, N.; Niiro, H.; Takenaka, K.; Nagafuji, K.; et al. Identification of the Human Eosinophil Lineage-Committed Progenitor: Revision of Phenotypic Definition of the Human Common Myeloid Progenitor. J. Exp. Med. 2009, 206, 183-193. [CrossRef] [PubMed]

11. Sehmi, R.D.J. Differentiation of Human Eosinophils. Marone G Hum. Eosinophils. Biol. Clin. Asp. Immunol. Basel, Karger 2000, 76, 29-44.

12. Hassani, M.; van Staveren, S.; van Grinsven, E.; Bartels, M.; Tesselaar, K.; Leijte, G.; Kox, M.; Pickkers, P.; Vrisekoop, Y.; Koenderman, L. Characterization of the Phenotype of Human Eosinophils and Their Progenitors in the Bone Marrow of Healthy Individuals. Haematologica 2020, 105, e52-e56. [CrossRef] [PubMed]

13. Zon, Y.L.I.; Yamaguchi, K.; Yee, E.A.; Albee, A.; Kimura, J.C.; Bennett, S.H.; Orkin, S.J.A. Expression of MRNA for the GATABinding Proteins in Human Eosinophils and Basophils: Potential Role in Gene Transcription. Blood 1993, 81, 3234-3241. [CrossRef]

14. Hirasawa, R.; Shimizu, R.; Takahashi, S.; Osawa, M.; Takayanagi, S.; Kato, Y.; Onodera, M.; Minegishi, N.; Yamamoto, M.; Fukao, K.; et al. Essential and Instructive Roles of GATA Factors in Eosinophil Development. J. Exp. Med. 2002, 195, $1379-1386$. [CrossRef]

15. Querfurth, E.; Schuster, M.; Kulessa, H.; Crispino, J.D.; Döderlein, G.; Orkin, S.H.; Graf, T.; Nerlov, C. Antagonism between $\mathrm{C} / \mathrm{EBP} \beta$ and FOG in Eosinophil Lineage Commitment of Multipotent Hematopoietic Progenitors. Genes Dev. 2000, 14, $2515-2525$. [CrossRef] [PubMed] 
16. Du Roure, C.; Versavel, A.; Doll, T.; Cao, C.; Pillonel, V.; Matthias, G.; Kaller, M.; Spetz, J.F.; Kopp, P.; Kohler, H.; et al. Hematopoietic Overexpression of FOG1 Does Not Affect B-Cells but Reduces the Number of Circulating Eosinophils. PLoS ONE 2014, 9. [CrossRef]

17. Mancini, E.; Sanjuan-Pla, A.; Luciani, L.; Moore, S.; Grover, A.; Zay, A.; Rasmussen, K.D.; Luc, S.; Bilbao, D.; O’Carroll, D.; et al. FOG-1 and GATA-1 Act Sequentially to Specify Definitive Megakaryocytic and Erythroid Progenitors. EMBO J. 2012, $31,351-365$. [CrossRef]

18. Milanovic, M.; Terszowski, G.; Struck, D.; Liesenfeld, O.; Carstanjen, D. IFN Consensus Sequence Binding Protein (Icsbp) Is Critical for Eosinophil Development. J. Immunol. 2014, 181, 5045-5053. [CrossRef] [PubMed]

19. Yamaguchi, Y.; Nishio, H.; Kishi, K.; Ackerman, S.J.S.T. C/EBPbeta and GATA-1 Synergistically Regulate Activity of the Eosinophil Granule Major Basic Protein Promoter: Implication for C/EBPbeta Activity in Eosinophil Gene Expression. Blood 1999, 94, 1429-1439. [CrossRef]

20. McNagny, K.M.; Sieweke, M.H.; Döderlein, G.; Graf, T.; Nerlov, C. Regulation of Eosinophil-Specific Gene Expression by a C/EBP-Ets Complex and GATA-1. EMBO J. 1998, 17, 3669-3680. [CrossRef] [PubMed]

21. Iwama, A.; Pan, J.; Zhang, P.; Reith, W.; Mach, B.; Tenen, D.G.; Sun, Z. Dimeric RFX Proteins Contribute to the Activity and Lineage Specificity of the Interleukin-5 Receptor $\alpha$ Promoter through Activation and Repression Domains. Mol. Cell. Biol. 1999, 19, 3940-3950. [CrossRef]

22. Iwama, A.; Osawa, M.; Hirasawa, R.; Uchiyama, N.; Kaneko, S.; Onodera, M.; Shibuya, K.; Shibuya, A.; Vinson, C.; Tenen, D.G.; et al. Reciprocal Roles for CCAAT/Enhancer Binding Protein (C/EBP) and PU.1 Transcription Factors in Langerhans Cell Commitment. J. Exp. Med. 2002, 195, 547-558. [CrossRef]

23. Zhang, D.E.; Zhang, P.; Wang, N.D.; Hetherington, C.J.; Darlington, G.J.; Tenen, D.G. Absence of Granulocyte Colony-Stimulating Factor Signaling and Neutrophil Development in CCAAT Enhancer Binding Protein Alpha-Deficient Mice. Proc. Natl. Acad. Sci. USA 1997, 94, 569-574. [CrossRef]

24. Satoh, T.; Kidoya, H.; Naito, H.; Yamamoto, M.; Takemura, N.; Nakagawa, K.; Yoshioka, Y.; Morii, E.; Takakura, N.; Takeuchi, O.; et al. Critical Role of Trib1 in Differentiation of Tissue-Resident M2-like Macrophages. Nature 2013, 495, 524-528. [CrossRef]

25. Iwasaki, H.; Mizuno, S.I.; Arinobu, Y.; Ozawa, H.; Mori, Y.; Shigematsu, H.; Takatsu, K.; Tenen, D.G.; Akashi, K. The Order of Expression of Transcription Factors Directs Hierarchical Specification of Hematopoietic Lineages. Genes Dev. 2006, 20, 3010-3021. [CrossRef]

26. Bedi, R.; Du, J.; Sharma, A.K.; Gomes, I.; Ackerman, S.J. Human C/EBP- $\varepsilon$ Activator and Repressor Isoforms Differentially Reprogram Myeloid Lineage Commitment and Differentiation. Blood 2009, 113, 317-327. [CrossRef]

27. Yamanaka, R.; Barlow, C.; Lekstrom-Himes, J.; Castilla, L.H.; Liu, P.P.; Eckhaus, M.; Decker, T.; Wynshaw-Boris, A.; Xanthopoulos, K.G. Impaired Granulopoiesis, Myelodysplasia, and Early Lethality in CCAAT/Enhancer Binding Protein $\varepsilon$-Deficient Mice. Proc. Natl. Acad. Sci. USA 1997, 94, 13187-13192. [CrossRef]

28. Bettigole, S.E.; Lis, R.; Adoro, S.; Lee, A.H.; Spencer, L.A.; Weller, P.F.; Glimcher, L.H. The Transcription Factor XBP1 Is Selectively Required for Eosinophil Differentiation. Nat. Immunol. 2015, 16, 829-837. [CrossRef] [PubMed]

29. Scott, E.W.; Simon, J.M.C.; Anastasi, H.S. Requirement of Transcription Factor PU.1 in the Development of Multiple Hematopoietic Lineages. Science 1994, 265, 1573-1577. [CrossRef] [PubMed]

30. Ackerman, S.J.; Du, J.; Xin, F.; Dekoter, R.; Mckercher, S.; Maki, R.; Singh, H.; Yamaguchi, Y. Eosinophilopoiesis. Respir. Med. 2000, 94, 1135-1138. [CrossRef]

31. Mack, E.A.; Stein, S.J.; Rome, K.S.; Xu, L.; Wertheim, G.B.; Melo, R.C.N.; Pear, W.S. Trib1 Regulates Eosinophil Lineage Commitment and Identity by Restraining the Neutrophil Program. Blood 2019, 133, 2413-2426. [CrossRef] [PubMed]

32. Zhang, L.F.A. SHP2 Tyrosine Phosphatase Stimulates CEBPA Gene Expression to Mediate Cytokine-Dependent Granulopoiesis. Blood 2011, 118, 2266-2274. [CrossRef] [PubMed]

33. Xia, L.X.; Hua, W.; Jin, Y.; Tian, B.P.; Qiu, Z.W.; Zhang, C.; Che, L.Q.; Zhou, H.B.; Wu, Y.F.; Huang, H.Q.; et al. Eosinophil Differentiation in the Bone Marrow Is Promoted by Protein Tyrosine Phosphatase SHP2. Cell Death Dis. 2016, 7, 1-13. [CrossRef]

34. Buitenhuis, M.; Van Deutekom, H.W.M.; Verhagen, L.P.; Castor, A.; Jacobsen, S.E.W.; Lammers, J.W.J.; Koenderman, L.; Coffer, P.J. Differential Regulation of Granulopoiesis by the Basic Helix-Loop-Helix Transcriptional Inhibitors Id1 and Id2. Blood 2005, 105, 4272-4281. [CrossRef] [PubMed]

35. Robinson, D.S.; Damia, R.; Zeibecoglou, K.; Molet, S.; North, J.; Yamada, T.; Kay, A.B.; Hamid, Q. CD34+/Interleukin-5R $\alpha$ Messenger RNA+ Cells in the Bronchial Mucosa in Asthma: Potential Airway Eosinophil Progenitors. Am. J. Respir. Cell Mol. Biol. 1999, 20, 9-13. [CrossRef] [PubMed]

36. Corry, D.B.; Folkesson, H.G.; Warnock, M.L.; Erle, D.J.; Matthay, M.A.; Wiener-Kronish, J.P.; Locksley, R.M. Interleukin 4, but Not Interleukin 5 or Eosinophils, Is Required in a Murine Model of Acute Airway Hyperreactivity. J. Exp. Med. 1996, 183, 109-117. [CrossRef]

37. Kopf, M.; Brombacher, F.; Hodgkin, P.D.; Ramsay, A.J.; Milbourne, E.A.; Dai, W.J.; Ovington, K.S.; Behm, C.A.; Köhler, G.; Young, I.G.; et al. IL-5-Deficient Mice Have a Developmental Defect in CD5+ B-1 Cells and Lack Eosinophilia but Have Normal Antibody and Cytotoxic T Cell Responses. Immunity 1996, 4, 15-24. [CrossRef]

38. Hui, C.C.K.; Rusta-Sallehy, S.; Asher, I.; Heroux, D.; Denburg, J.A. The Effects of Thymic Stromal Lymphopoietin and Il-3 on Human Eosinophil-Basophil Lineage Commitment: Relevance to Atopic Sensitization. Immun. Inflamm. Dis. 2014, 2, 44-55. [CrossRef] [PubMed] 
39. Salter, B.M.A.; Smith, S.G.; Mukherjee, M.; Plante, S.; Krisna, S.; Nusca, G.; Oliveria, J.P.; Irshad, A.; Gauvreau, G.M.; Chakir, J.; et al. Human Bronchial Epithelial Cell-Derived Factors from Severe Asthmatic Subjects Stimulate Eosinophil Differentiation. Am. J. Respir. Cell Mol. Biol. 2018, 58. [CrossRef]

40. Johnston, L.K.; Hsu, C.-L.; Krier-Burris, R.A.; Chhiba, K.D.; Chien, K.B.; McKenzie, A.; Berdnikovs, S.; Bryce, P.J. IL-33 Precedes IL-5 in Regulating Eosinophil Commitment and Is Required for Eosinophil Homeostasis. J. Immunol. 2016, 197, $3445-3453$. [CrossRef] [PubMed]

41. Boberg, E.; Johansson, K.; Malmhäll, C.; Weidner, J.; Rådinger, M. House Dust Mite Induces Bone Marrow Il-33responsive ILC2S and TH Cells. Int. J. Mol. Sci. 2020, 21, 3751. [CrossRef] [PubMed]

42. Stolarski, B.; Kurowska-Stolarska, M.; Kewin, P.; Xu, D.; Liew, F.Y. IL-33 Exacerbates Eosinophil-Mediated Airway Inflammation. J. Immunol. 2010, 185, 3472-3480. [CrossRef]

43. Allakhverdi, Z.; Comeau, M.R.; Smith, D.E.; Toy, D.; Endam, L.M.; Desrosiers, M.; Liu, Y.J.; Howie, K.J.; Denburg, J.A.; Gauvreau, G.M.; et al. CD34+ Hemopoietic Progenitor Cells Are Potent Effectors of Allergic Inflammation. J. Allergy Clin. Immunol. 2009, 123, 472-479. [CrossRef] [PubMed]

44. Baba, Y.; Maeda, K.; Yashiro, T.; Inage, E.; Kasakura, K.; Suzuki, R.; Niyonsaba, F.; Hara, M.; Tanabe, A.; Ogawa, H.; et al. GATA2 Is a Critical Transactivator for the Human IL1RL1/ST2 Promoter in Mast Cells/Basophils: Opposing Roles for GATA2 and GATA1 in Human IL1RL1/ST2 Gene Expression. J. Biol. Chem. 2012, 287, 32689-32696. [CrossRef]

45. Smith, S.G.; Gugilla, A.; Mukherjee, M.; Merim, K.; Irshad, A.; Tang, W.; Kinoshita, T.; Watson, B.; Oliveria, J.P.; Comeau, M.; et al. Thymic Stromal Lymphopoietin and IL-33 Modulate Migration of Hematopoietic Progenitor Cells in Patients with Allergic Asthma. J. Allergy Clin. Immunol. 2015, 135, 1594-1602. [CrossRef]

46. Tang, W.; Smith, S.G.; Du, W.; Gugilla, A.; Du, J.; Oliveria, J.P.; Howie, K.; Salter, B.M.; Gauvreau, G.M.; O’Byrne, P.M.; et al. Interleukin-25 and Eosinophils Progenitor Cell Mobilization in Allergic Asthma. Clin. Transl. Allergy 2018, 8. [CrossRef] [PubMed]

47. Saenz, S.A.; Siracusa, M.C.; Perrigoue, J.G.; Spencer, S.P.; Urban, J.F.; Tocker, J.E.; Budelsky, A.L.; Kleinschek, M.A.; Kastelein, R.A.; Kambayashi, T.; et al. IL25 Elicits a Multipotent Progenitor Cell Population That Promotes T H 2 Cytokine Responses. Nature 2010, 464, 1362-1366. [CrossRef]

48. Saenz, S.A.; Siracusa, M.C.; Monticelli, L.A.; Ziegler, C.G.K.; Kim, B.S.; Brestoff, J.R.; Peterson, L.W.; John Wherry, E.; Goldrath, A.W.; Bhandoola, A.; et al. IL-25 Simultaneously Elicits Distinct Populations of Innate Lymphoid Cells and Multipotent Progenitor Type 2 (MPPtype2) Cells. J. Exp. Med. 2013, 210, 1823-1837. [CrossRef]

49. Braccioni, F.; Dorman, S.C.; O’Byrne, P.M.; Inman, M.D.; Denburg, J.A.; Parameswaran, K.; Baatjes, A.J.; Foley, R. The Effect of Cysteinyl Leukotrienes on Growth of Eosinophil Progenitors From Peripheral Blood and Bone Marrow of Atopic Subjects. J. Allergy Clin. Immunol. 2002, 110, 96-101. [CrossRef] [PubMed]

50. Lamkhioued, B.; Abdelilah, S.G.; Hamid, Q.; Mansour, N.; Delespesse, G.; Renzi, P.M. The CCR3 Receptor Is Involved in Eosinophil Differentiation and Is Up-Regulated by Th2 Cytokines in CD34 + Progenitor Cells. J. Immunol. 2003, 170, 537-547. [CrossRef]

51. Sehmi, R.; Howie, K.; Sutherland, D.R.; Schragge, W.; O’Byrne, P.M.; Denburg, J.A. Increased Levels of CD34+ Hemopoietic Progenitor Cells in Atopic Subjects. Am. J. Respir. Cell Mol. Biol. 1996, 15, 645-654. [CrossRef]

52. Wang, C.H.; Hsieh, W.Y.; Shih, L.Y.; Lin, H.C.; Liu, C.Y.; Chung, K.F.; Kuo, H.P. Increased Progenitor Cell Proliferation in the Peripheral Blood of Patients with Bronchial Asthma:The Role of Nitric Oxide. J. Allergy Clin. Immunol. 1999, 104, 803-810. [CrossRef]

53. Denburg, J.A.; Telizyn, S.; Belda, A.; Dolovich, J.; Bienenstock, J. Increased Numbers of Circulating Basophil Progenitors in Atopic Patients. J. Allergy Clin. Immunol. 1985, 76, 466-472. [CrossRef]

54. Gibson, P.G.; Dolovich, J.; Girgis-Gabardo, A.; Morris, M.M.; Anderson, M.; Hargreave, F.E.; Denburg, J.A. The Inflammatory Response in Asthma Exacerbation: Changes in Circulating Eosinophils, Basophils and Their Progenitors. Clin. Exp. Allergy 1990, 20, 661-668. [CrossRef]

55. Gibson, P.G.; Manning, P.J.; Byrne, P.M.O.; Girgis-gabardo, A.; Dolovich, J.; Denburg, J.A.; Hargreave, F.E. Allergen-Induced Asthmatic Responses. Am. Rev. Respir. Dis. 1991, 143, 331-335. [CrossRef] [PubMed]

56. Gauvreau, G.M.; O’Byrne, P.M.; Moqbel, R.; Velazquez, J.; Watson, R.M.; Howie, K.J.; Denburg, J.A. Enhanced Expression of GM-CSF in Differentiating Eosinophils of Atopic and Atopic Asthmatic Subjects. Am. J. Respir. Cell Mol. Biol. 1998, $19,55-62$. [CrossRef]

57. Kuo, H.P.; Wang, C.H.; Lin, H.C.; Hwang, K.S.; Liu, S.L.; Chung, K.F. Interleukin-5 in Growth and Differentiation of Blood Eosinophil Progenitors in Asthma: Effect of Glucocorticoids. Br. J. Pharmacol. 2001, 134, 1539-1547. [CrossRef] [PubMed]

58. Smith, S.G.; Chen, R.; Kjarsgaard, M.; Huang, C.; Oliveria, J.-P.; O’Byrne, P.M.; Gauvreau, G.M.; Boulet, L.-P.; Lemiere, C.; Martin, J.; et al. Increased Numbers of Activated Group 2 Innate Lymphoid Cells in the Airways of Patients with Severe Asthma and Persistent Airway Eosinophilia. J. Allergy Clin. Immunol. 2016, 137, 75-86.e8. [CrossRef] [PubMed]

59. Sehmi, R.; Smith, S.G.; Kjarsgaard, M.; Radford, K.; Boulet, L.P.; Lemiere, C.; Prazma, C.M.; Ortega, H.; Martin, J.G.; Nair, P. Role of Local Eosinophilopoietic Processes in the Development of Airway Eosinophilia in Prednisone-Dependent Severe Asthma. Clin. Exp. Allergy 2016, 46, 793-802. [CrossRef] [PubMed]

60. Cameron, L.; Christodoulopoulos, P.; Lavigne, F.; Nakamura, Y.; Eidelman, D.; McEuen, A.; Walls, A.; Tavernier, J.; Minshall, E.; Moqbel, R.; et al. Evidence for Local Eosinophil Differentiation Within Allergic Nasal Mucosa: Inhibition with Soluble IL-5 Receptor. J. Immunol. 2000, 164, 1538-1545. [CrossRef] 
61. Menzies-Gow, A.N.; Flood-Page, P.T.; Robinson, D.S.; Kay, A.B. Effect of Inhaled Interleukin-5 on Eosinophil Progenitors in the Bronchi and Bone Marrow of Asthmatic and Non-Asthmatic Volunteers. Clin. Exp. Allergy J. Br. Soc. Allergy Clin. Immunol. 2007, 37, 1023-1032. [CrossRef]

62. Sehmi, R.; Dorman, S.; Baatjes, A.; Watson, R.; Foley, R.; Ying, S.U.N.; Robinson, S.; Kay, A.B.; Byrne, P.M.O.; Denburg, J.A. Allergen-Induced Fluctuation in CC Chemokine Receptor 3 Expression on Bone Marrow CD34+ Cells from Asthmatic Subjects: Significance for Mobilization of Haemopoietic Progenitor Cells in Allergic Inflammation. Immunology 2003, 109, 536-546. [CrossRef]

63. Dorman, S.C.; Babirad, I.; Post, J.; Watson, R.M.; Foley, R.; Jones, G.L.; O’Byrne, P.M.; Sehmi, R. Progenitor Egress from the Bone Marrow after Allergen Challenge: Role of Stromal Cell-Derived Factor $1 \alpha$ and Eotaxin. J. Allergy Clin. Immunol. 2005, 115, 501-507. [CrossRef] [PubMed]

64. Catalli, A.E.; Thomson, J.V.; Babirad, I.M.; Duong, M.; Doyle, T.M.; Howie, K.J.; Newbold, P.; Craggs, R.I.; Foster, M.; Gauvreau, G.M.; et al. Modulation of Beta1-Integrins on Hemopoietic Progenitor Cells after Allergen Challenge in Asthmatic Subjects. J. Allergy Clin. Immunol. 2008, 122, 803-810. [CrossRef] [PubMed]

65. Schwartz, J.T.; Magier, A.Z.; Marshall, S.A.F.P. Eosinophil Progenitor Cell Blood Levels Inversely Correlate with Disease Control in Pediatric Patients with Asthma. J. Allergy Clin. Immunol. 2019, 143, AB5. [CrossRef]

66. Pageau, R.; Gauvreau, G.; Seguin, R.; Carballo, D.; Anjou, H.D.; Campbell, H.; Watson, R.; Parry-Billings, M.; Killian, K.R.P. TPI ASM8 Decreases Inflammatory Markers and Improves Airway Responsiveness in Asthmatics. J. Allergy Clin. Immunol. 2011, 127, AB82. [CrossRef]

67. Imaoka, H.; Campbell, H.; Babirad, I.; Watson, R.M.; Mistry, M.; Sehmi, R.; Gauvreau, G.M. TPI ASM8 Reduces Eosinophil Progenitors in Sputum after Allergen Challenge. Clin. Exp. Allergy 2011, 1740-1746. [CrossRef] [PubMed]

68. Panousis, C.; Dhagat, U.; Edwards, K.M.; Rayzman, V.; Hardy, M.P.; Braley, H.; Gauvreau, G.M.; Hercus, T.R.; Smith, S.; Sehmi, R.; et al. CSL311, a Novel, Potent, Therapeutic Monoclonal Antibody for the Treatment of Diseases Mediated by the Common $\beta$ Chain of the IL-3, GM-CSF and IL-5 Receptors. MAbs 2016, 8, 436-453. [CrossRef] [PubMed]

69. Neighbour, H.; Boulet, L.; Lemiere, C.; Sehmi, R.; Leigh, R.; Sousa, A.R.; Martin, J.; Dallow, N.; Gilbert, J.; Allen, A. Safety and Efficacy of an Oral CCR3 Antagonist in Patients with Asthma and Eosinophilic Bronchitis: A Randomized. Placebo-Controll. Clin. Trial Exp. Allergy 2013, 2, 508-516. [CrossRef]

70. Menzies-Gow, A.; Flood-Page, P.; Sehmi, R.; Burman, J.; Hamid, Q.; Robinson, D.S.; Kay, A.B.; Denburg, J. Anti-IL-5 (Mepolizumab) Therapy Induces Bone Marrow Eosinophil Maturational Arrest and Decreases Eosinophil Progenitors in the Bronchial Mucosa of Atopic Asthmatics. J. Allergy Clin. Immunol. 2003, 111, 714-719. [CrossRef] [PubMed]

71. Mukherjee, M.; Paramo, F.A.; Kjarsgaard, M.; Salter, B.; Nair, G.; LaVigne, N.; Radford, K.; Sehmi, R.; Nair, P. Weight-Adjusted Intravenous Reslizumab in Severe Asthma with Inadequate Response to Fixed-Dose Subcutaneous Mepolizumab. Am. J. Respir. Crit. Care Med. 2018, 197. [CrossRef] [PubMed]

72. Sehmi, R.; Lim, H.F.; Mukherjee, M.; Huang, C.; Radford, K.; Newbold, P.; Boulet, L.P.; Dorscheid, D.; Martin, J.G.; Nair, P. Benralizumab Attenuates Airway Eosinophilia in Prednisone-Dependent Asthma. J. Allergy Clin. Immunol. 2018, 141, 15291532.e8. [CrossRef]

73. Parameswaran, K.; Watson, R.; Gauvreau, G.M.; Sehmi, R.; O’Byrne, P.M. The Effect of Pranlukast on Allergen-Induced Bone Marrow Eosinophilopoiesis in Subjects with Asthma. Am. J. Respir. Crit. Care Med. 2004, 169, 915-920. [CrossRef] [PubMed]

74. Gauvreau, G.M.; Pageau, R.; Séguin, R.; Carballo, D.; Gauthier, J.; D’Anjou, H.; Campbell, H.; Watson, R.; Mistry, M.; ParryBillings, M.; et al. Dose-Response Effects of TPI ASM8 in Asthmatics after Allergen. Allergy Eur. J. Allergy Clin. Immunol. 2011, 66, 1242-1248. [CrossRef] [PubMed]

75. Komai, M.; Tanaka, H.; Nagao, K.; Ishizaki, M.; Kajiwara, D.; Miura, T.; Ohashi, H.; Haba, T.; Kawakami, K.; Sawa, E.; et al. A Novel CC-Chemokine Receptor 3 Antagonist, Ki19003, Inhibits Airway Eosinophilia and Subepithelial/Peribronchial Fibrosis Induced by Repeated Antigen Challenge in Mice. J. Pharmacol Sci. 2010, 112, 203-213. [CrossRef] [PubMed]

76. Gauvreau, G.M.; FitzGerald, J.M.; Boulet, L.P.; Watson, R.M.; Hui, L.; Villineuve, H.; Scime, T.X.; Schlatman, A.R.; Obminski, C.; Kum, J.; et al. The Effects of a CCR3 Inhibitor, AXP1275, on Allergen-Induced Airway Responses in Adults with Mild-to-Moderate Atopic Asthma. Clin. Exp. Allergy 2018, 48, 445-451. [CrossRef]

77. Grozdanovic, M.; Laffey, K.G.; Abdelkarim, H.; Hitchinson, B.; Harijith, A.; Moon, H.G.; Park, G.Y.; Rousslang, L.K.; Masterson, J.C.; Furuta, G.T.; et al. Novel Peptide Nanoparticle-Biased Antagonist of CCR3 Blocks Eosinophil Recruitment and Airway Hyperresponsiveness. J. Allergy Clin. Immunol. 2019, 143, 669-680.e12. [CrossRef] [PubMed]

78. Pavord, I.D.; Korn, S.; Howarth, P.; Bleecker, E.R.; Buhl, R.; Keene, O.N. Mepolizumab for Severe Eosinophilic Asthma (DREAM): A Multicentre, Double-Blind, Placebo-Controlled Trial. Lancet 2012, 380, 651-659. [CrossRef]

79. Bel, E.H.; Wenzel, S.E.; Thompson, P.J.; Prazma, C.M.; Keene, O.N.; Yancey, S.W. Oral Glucocorticoid-Sparing Effect of Mepolizumab in Eosinophilic Asthma. N. Engl. J. Med. 2014, 371, 1189-1197. [CrossRef]

80. Leckie, M.J.; Brinke, A.T.; Khan, J.; Diamant, Z.; O'Connor, B.J.; Walls, C.M.M.A.; Cowley, H.C.; Chung, K.F.; Djukanovic, R.; Hansel, T.T.; et al. Effects of an Interleukin-5 Blocking Monoclonal Antibody on Eosinophils, Airway Hyper-Responsìveness, and the Late Asthmatic Response. Lancet 2000, 356, 2144-2148. [CrossRef]

81. Büttner, C.; Lun, A.; Splettstoesser, T.; Kunkel, G.R.H. Monoclonal Antiinterleukin-5 Treatment Suppresses Eosinophil but Not T-cell Functions. Eur. Respir. J. 2003, 21, 799-803. [CrossRef] 
82. Flood-Page, P.T.; Menzies-Gow, A.N.; Kay, A.B. Eosinophil's Role Remains Uncertain as Anti-Interleukin-5 Only Partially Depletes Numbers in Asthmatic Airway. Am. J. Respir. Crit. Care Med. 2003, 167, 199-204. [CrossRef]

83. Flood-Page, P.; Swenson, C.; Faiferman, I.; Matthews, J.; Williams, M.B.L.; Robinson, D.; Wenzel, S.; Busse, W.; Hansel, T.T.B.N. A Study to Evaluate Safety and Efficacy of Mepolizumab in Patients with Moderate Persistent Asthma. Am. J. Respir. Crit. Care Med. 2007, 176, 1062-1071. [CrossRef]

84. Nair, P.; Pizzichini, M.M.M.; Kjarsgaard, M.; Inman, M.D.; Efthimiadis, A.P.E.; Hargreave, F.E.O.P. Mepolizumab for PrednisoneDependent Asthma with Sputum Eosinophilia. N. Engl. J. Med. 2009, 360, 985-993. [CrossRef] [PubMed]

85. Haldar, P.; Brightling, C.E.; Hargadon, B.; Gupta, S.; Monteiro, W.; Sousa, A.M.; Bradding, P.; Green, R.H.; Wardlaw, A.J. Mepolizumab and Exacerbations of Refractory Eosinophilic Asthma. N. Engl. J. Med. 2009, 360, 973-984. [CrossRef]

86. Kips, J.C.; O'Connor, B.J.; Langley, S.J.; Woodcock, A.; Kerstjens, H.A.M.; Danzig, M.; Cuss, F. Effect of SCH55700, a Humanized Anti-Human Interleukin-5 Antibody, in Severe Persistent Asthma. Am. J. Respir. Crit. Care Med. 2003, 167, 1655-1659. [CrossRef]

87. Castro, M.; Mathur, S.; Hargreave, F.; Boulet, L.-P.; Xie, F.; Young, J.; Henkel, T. Reslizumab for Poorly Controlled, Eosinophilic Asthma. Am. J. Respir. Crit. Care Med. 2011, 184, 1125-1132. [PubMed]

88. Castro, M.; Zangrilli, J.; Wechsler, M.E.; Bateman, E.D.; Brusselle, G.G.; Bardin, P.; Murphy, K.; Maspero, J.F.; O’Brien, C.K.S. Reslizumab for Inadequately Controlled Asthma With Elevated Blood Eosinophil Counts: Results From Two Multicentre, Parallel, Double-Blind, Randomised, Placebo-Controlled, Phase 3 Trials. Lancet Respir. Med. 2015, 3, 355-366. [CrossRef]

89. Corren, J.; Weinstein, S.; Janka, L.; Zangrilli, J.; Garin, M. Phase 3 Study of Reslizumab in Patients With Poorly Controlled Asthma: Effects Across a Broad Range of Eosinophil Counts. Chest 2016, 150, 799-810. [CrossRef]

90. Bjermer, L.; Lemiere, C.; Maspero, J.; Weiss, S.; Zangrilli, J.; Germinaro, M. Reslizumab for Inadequately Controlled Asthma With Elevated Blood Eosinophil Levels: A Randomized Phase 3 Study. Chest 2016, 150, 789-798. [CrossRef] [PubMed]

91. Murphy, K.; Jacobs, J.; Bjermer, L.; Fahrenholz, J.M.; Shalit, Y.; Garin, M.; Zangrilli, J.; Castro, M. Long-Term Safety and Efficacy of Reslizumab in Patients with Eosinophilic Asthma. J. Allergy Clin. Immunol. Pract. 2017, 5, 1572-1581.e3. [CrossRef]

92. Ibrahim, H.; O'Sullivan, R.; Casey, D.; Murphy, J.; MacSharry, J.; Plant, B.J.; Murphy, D.M. The Effectiveness of Reslizumab in Severe Asthma Treatment: A Real-World Experience. Respir. Res. 2019, 20, 1-5. [CrossRef]

93. Chanez, P.; McDonald, M. Early Decreases in Blood Eosinophil Levels with Reslizumab. J. Allergy Clin. Immunol. 2019, 143, 1653-1655. [CrossRef]

94. Laviolette, M.; Gossage, D.L.; Gauvreau, G.; Leigh, R.; Olivenstein, R.; Katial, R.; Busse, W.W.; Wenzel, S.; Wu, Y.; Datta, V.; et al. Effects of Benralizumab on Airway Eosinophils in Asthmatic Patients with Sputum Eosinophilia. J. Allergy Clin. Immunol. 2013, 132, 1086-1096.e5. [CrossRef] [PubMed]

95. Pham, T.H.; Damera, G.; Newbold, P.; Ranade, K. Reductions in Eosinophil Biomarkers by Benralizumab in Patients with Asthma. Respir. Med. 2016, 111, 21-29. [CrossRef]

96. Busse, W.W.; Katial, R.; Gossage, D.; Sari, S.; Wang, B.; Kolbeck, R.; Coyle, A.J.K.M.; Spitalny, G.L.; Kiener, P.A.; Geba, G.P.M.N. Safety Profile, Pharmacokinetics, and Biologic Activity of MEDI-563, an Anti-IL-5 Receptor $\alpha$ Antibody, in a Phase I Study of Subjects with Mild Asthma. J. Allergy Clin. Immunol. 2010, 125, 1244. [CrossRef] [PubMed]

97. Wenzel, S.; Ford, L.; Pearlman, D.; Spector, S.; Sher, L.; Skobieranda, F.; Wang, L.; Kirkesseli, S.; Rocklin, R.; Bock, B.; et al. Dupilumab in Persistent Asthma with Elevated Eosinophil Levels. N. Engl. J. Med. 2013, 368, 2455-2466. [CrossRef] [PubMed]

98. Rabe, K.F.; Nair, P.; Brusselle, G.; Maspero, J.F.; Castro, M.; Sher, L.; Zhu, H.; Hamilton, J.D.; Swanson, B.N.; Khan, A.; et al. Efficacy and Safety of Dupilumab in Glucocorticoid-Dependent Severe Asthma. N. Engl. J. Med. 2018, 378, 2475-2485. [CrossRef]

99. Castro, M.; Corren, J.; Pavord, I.D.; Maspero, J.; Wenzel, S.; Rabe, K.F.; Busse, W.W.; Ford, L.; Sher, L.; FitzGerald, J.M.; et al. Dupilumab Efficacy and Safety in Moderate-to-Severe Uncontrolled Asthma. N. Engl. J. Med. 2018, 378, 2486-2496. [CrossRef] [PubMed]

100. Edris, A.; De Feyter, S.; Maes, T.; Joos, G.; Lahousse, L. Monoclonal Antibodies in Type 2 Asthma: A Systematic Review and Network Meta-Analysis. Respir. Res. 2019, 20, 1-15. [CrossRef]

101. Hanania, N.A.; Korenblat, P.; Chapman, K.R.; Bateman, E.D.; Kopecky, P.; Paggiaro, P.; Yokoyama, A.; Olsson, J.; Gray, S.; Holweg, C.T.J.; et al. Efficacy and Safety of Lebrikizumab in Patients with Uncontrolled Asthma (LAVOLTA I and LAVOLTA II): Replicate, Phase 3, Randomised, Double-Blind, Placebo-Controlled Trials. Lancet Respir. Med. 2016, 4, 781-796. [CrossRef]

102. Trifilieff, A.; Bench, A.; Hanley, M.; Bayley, D.; Campbell, E.; Whittaker, P. PPAR- $\alpha$ and $-\gamma$ but Not $-\delta$ Agonists Inhibit Airway Inflammation in a Murine Model of Asthma: In Vitro Evidence for an NF-KB-Independent Effect. Br. J. Pharmacol. 2003, 139, 163-171. [CrossRef]

103. Smith, S.G.; Hill, M.; Oliveria, J.P.; Watson, B.M.; Baatjes, A.J.; Dua, B.; Howie, K.; Campbell, H.; Watson, R.M.; Sehmi, R.; et al. Evaluation of Peroxisome Proliferator-Activated Receptor Agonists on Interleukin-5-Induced Eosinophil Differentiation. Immunology 2014, 142, 484-491. [CrossRef]

104. Kaler, M.; Barcochia, A.V.; Weir, N.A.; Cuento, R.A.; Stylianou, M.; Roth, M.J.; Filie, A.C.; Vaughey, E.C.; Nathan, S.D. A Randomized, Placebo-Controlled Double-Blinded, Crossover Trial of Pioglitazone for Severe Asthma. J. Allergy Clin. Immunol. 2017, 140, 1716-1718. [CrossRef] [PubMed]

105. Chen, Z.G.; Zhang, T.T.; Li, H.T.; Chen, F.H.; Zou, X.L.; Ji, J.Z.; Chen, H. Neutralization of TSLP Inhibits Airway Remodeling in a Murine Model of Allergic Asthma Induced by Chronic Exposure to House Dust Mite. PLoS ONE 2013, 8. [CrossRef] 
106. Cheng, D.T.; Ma, C.; Niewoehner, J.; Dahl, M.; Tsai, A.; Zhang, J.; Gonsiorek, W.; Apparsundaram, S.; Pashine, A.; Ravindran, P.; et al. Thymic Stromal Lymphopoietin Receptor Blockade Reduces Allergic Inflammation in a Cynomolgus Monkey Model of Asthma. J. Allergy Clin. Immunol. 2013, 132, 455-462. [CrossRef] [PubMed]

107. Shi, L.; Leu, S.W.; Xu, F.; Zhou, X.; Yin, H.; Cai, L.; Zhang, L. Local Blockade of TSLP Receptor Alleviated Allergic Disease by Regulating Airway Dendritic Cells. Clin. Immunol. 2008, 129, 202-210. [CrossRef]

108. Gauvreau, G.M.; O’Byrne, P.M.; Boulet, L.P.; Wang, Y.; Cockcroft, D.; Bigler, J.; FitzGerald, J.M.; Boedigheimer, M.; Davis, B.E.; Dias, C.; et al. Effects of an Anti-TSLP Antibody on Allergen-Induced Asthmatic Responses. N. Engl. J. Med. 2014, 370, 2102-2110. [CrossRef]

109. Pham, T.-H.; Ren, P.; Parnes, J.R.; Griffiths, J.M. Tezepelumab Reduces Multiple Key Inflammatory Biomarkers in Patients with Severe, Uncontrolled Asthma in the Phase 2b PATHWAY Study. Am. J. Respir. Crit. Care Med. 2019, 224, A2677. [CrossRef]

110. Lee, H.Y.; Rhee, C.K.; Kang, J.Y.; Byun, J.H.; Choi, J.Y.; Kim, S.J.; Kim, Y.K.; Kwon, S.S.; Lee, S.Y. Blockade of IL-33/ST2 Ameliorates Airway Inflammation in a Murine Model of Allergic Asthma. Exp. Lung Res. 2014, 40, 66-76. [CrossRef] [PubMed]

111. Allinne, J.; Scott, G.; Lim, W.K.; Birchard, D.; Erjefält, J.S.; Sandén, C.; Ben, L.H.; Agrawal, A.; Kaur, N.; Kim, J.H.; et al. IL-33 Blockade Affects Mediators of Persistence and Exacerbation in a Model of Chronic Airway Inflammation. J. Allergy Clin. Immunol. 2019, 144, 1624-1637.e10. [CrossRef]

112. Chen, Y.L.; Gutowska-Owsiak, D.; Hardman, C.S.; Westmoreland, M.; MacKenzie, T.; Cifuentes, L.; Waithe, D.; Lloyd-Lavery, A.; Marquette, A.; Londei, M.; et al. Proof-of-Concept Clinical Trial of Etokimab Shows a Key Role for IL-33 in Atopic Dermatitis Pathogenesis. Sci. Transl. Med. 2019, 11. [CrossRef] [PubMed]

113. Chinthrajah, S.; Cao, S.; Liu, C.; Lyu, S.C.; Sindher, S.B.; Long, A.; Sampath, V.; Petroni, D.; Londei, M.; Nadeau, K.C. Phase 2a Randomized, Placebo-Controlled Study of Anti-IL-33 in Peanut Allergy. JCI Insight 2019, 4, 1-14. [CrossRef] [PubMed]

114. AnaptysBio. Proof of concept study to investigate ANB020 activity in adult patients with severe eosinophilic asthma.

115. Sharkhuu, T.; Matthaei, K.I.; Forbes, E.; Mahalingam, S.; Hogan, S.P.; Hansbro, P.M.; Foster, P.S. Mechanism of Interleukin-25 (IL-17E)-Induced Pulmonary Inflammation and Airways Hyper-Reactivity. Clin. Exp. Allergy 2006, 36, 1575-1583. [CrossRef] [PubMed]

116. Angkasekwinai, P.; Park, H.; Wang, Y.H.; Wang, Y.H.; Seon, H.C.; Corry, D.B.; Liu, Y.J.; Zhu, Z.; Dong, C. Interleukin 25 Promotes the Initiation of Proallergic Type 2 Responses. J. Exp. Med. 2007, 204, 1509-1517. [CrossRef]

117. Hurst, S.D.; Muchamuel, T.; Gorman, D.M.; Gilbert, J.M.; Clifford, T.; Kwan, S.; Menon, S.; Seymour, B.; Jackson, C.; Kung, T.T.; et al. New IL-17 Family Members Promote Th1 or Th2 Responses in the Lung: In Vivo Function of the Novel Cytokine IL-25. J. Immunol. 2002, 169, 443-453. [CrossRef]

118. Ballantyne, S.J.; Barlow, J.L.; Jolin, H.E.; Nath, P.; Williams, A.S.; Chung, K.F.; Sturton, G.; Wong, S.H.; McKenzie, A.N.J. Blocking IL-25 Prevents Airway Hyperresponsiveness in Allergic Asthma. J. Allergy Clin. Immunol. 2007, 120, 1324-1331. [CrossRef]

119. Gregory, L.G.; Jones, C.P.; Walker, S.A.; Sawant, D.; Gowers, K.H.C.; Campbell, G.A.; McKenzie, A.N.J.; Lloyd, C.M. IL-25 Drives Remodelling in Allergic Airways Disease Induced by House Dust Mite. Thorax 2013, 68, 82-90. [CrossRef] 